(c) American Dairy Science Association, 2004.

\title{
Fat Digestion in Veal Calves Fed Milk Replacers Low or High in Calcium and Containing Either Casein or Soy Protein Isolate
}

\author{
C. Yuangklang, ${ }^{1}$ Th. Wensing, ${ }^{1}$ L. Van den Broek, ${ }^{2}$ S. Jittakhot, ${ }^{1}$ and A. C. Beynen ${ }^{1}$ \\ ${ }^{1}$ Department of Nutrition, Faculty of Veterinary Medicine, \\ Utrecht University, 3508 TD Utrecht, The Netherlands \\ ${ }^{2}$ Research and Development Department, \\ Van Drie Group, Mijdrecht, The Netherlands
}

\begin{abstract}
The hypothesis tested was that the inhibitory effect of dietary soy protein versus casein on fat digestion in veal calves would be smaller when diets were fed with high instead of low calcium content. Male calves, $1 \mathrm{wk}$ of age, were fed 1 of 4 experimental milk replacers in a $2 \times 2$ factorial design. There were 19 animals per dietary group. The milk replacers contained either casein or soy protein isolate as variable protein source and were either low or high in calcium. Body weight gain was not significantly affected by the experimental diets. Soy protein isolate versus casein significantly reduced apparent fat digestibility. High versus low calcium intake also depressed fat digestion. The protein effect was smaller (2.9\% units) for the high than the low calcium diets ( $3.6 \%$ units), but the interaction did not reach statistical significance. Soy protein isolate versus casein raised fecal bile acid excretion and so did high versus low calcium intake. The difference in bile acid excretion between the soy and casein containing diets was significantly greater for the high than low calcium diets. The absorption of phosphorus, calcium, and magnesium was higher for the casein diets than for the soy-containing diets. This study shows for the first time that soy protein isolate versus casein depressed fat digestion and raised fecal bile acid excretion in veal calves.
\end{abstract}

(Key words: casein, soy protein isolate, fat digestion, veal calf)

\section{INTRODUCTION}

Soy protein preparations are commonly incorporated in milk replacers for veal calf production (Best, 1995). Growth performance of veal calves fed milk replacers containing soy protein is inferior to calves fed milk proteins (Nitsan et al., 1971; Beynen and Van Gils, 1983;

Received May 22, 2003

Accepted September 5, 2003.

Corresponding author: A. Beynen; e-mail: a.c.beynen@vet.uu.nl.
Lallès et al., 1995; Xu et al., 1997). The lowering of fat digestibility in part is responsible for the poor growth performance seen when calves are fed soy protein (Van Kempen and Huisman, 1991). The low fat digestibility induced by soy protein has been attributed to allergens and/or anti-nutritional factors damaging the small intestinal mucosa (Van Kempen and Huisman, 1991) and to lack of clotting in the abomasum leading to enhanced outflow of fat (Beynen and Van Gils, 1983). Another mechanism explaining why dietary soy protein lowers fat digestibility involves the production of extra calcium phosphate sediment in the intestinal digesta. When compared with soy protein, casein is a highly phosphorylated protein (Xu et al., 1997). Unlike casein, soy protein will not attract calcium from the calcium phosphate sediment so that more sediment remains in the small intestinal lumen (Xu et al., 1997). This sediment binds bile acids (Govers et al., 1994), leading to a lower availability of bile acids for the process of fat digestion. The result is that bile acids excretion in feces is elevated and fat digestion is diminished (Van der Meer et al., 1985; Xu et al., 1997).

High calcium intake has been shown to decrease fat digestion and to enhance fecal bile acid excretion in veal calves, which can also be explained by the formation of extra calcium phosphate sediment (Xu et al., 1998) rather than by the formation of calcium fatty acid soaps (Beynen et al., 2002). In rabbits, it has been shown that the inhibitory effect of soy protein versus casein on fat digestion was smaller when fed diets high instead of low in calcium (Van der Meer et al., 1985). Additional calcium added to a casein containing diet would bind to the phosphoserine residues of the casein, thus reducing solubilization of the calcium phosphate sediment (Van der Meer et al., 1985). In other words, when diets containing either casein or soy protein are high instead of low in calcium, the difference in the amount of calcium phosphate sediment is smaller. It can thus be hypothesized that a high calcium intake would also diminish the inhibitory effect of soy protein versus casein on fat digestion. In the present study with veal calves the hypothesis was tested. 


\section{MATERIALS AND METHODS}

\section{Calves and Experimental Diets}

Seventy-six male Dutch Friesian-Holstein calves were used. The calves, about 1 wk of age, were purchased at a local market. Their BW was $47 \pm 3.96 \mathrm{~kg}$ (mean $\pm \mathrm{SD}, \mathrm{n}=76$ ). The calves were kept individually in wooden stalls $(70 \times 170 \mathrm{~cm})$ with slatted floors. The stalls were placed in a ventilated room. The calves were fed twice a day (0630 and $1600 \mathrm{~h}$ ) with a reconstituted milk replacer offered in plastic buckets. They were weighed between 1100 and $1200 \mathrm{~h}$ in wk 0,6 and 23 of the experiment.

On arrival (wk 0), the calves were divided into 4 groups of 19 calves each so that BW distributions of the groups were similar. The calves were fed 1 of 4 experimental starter diets. After $7 \mathrm{wk}$, the calves received the corresponding finisher diets for $16 \mathrm{wk}$. The diets contained either casein or soy protein isolate as variable source of protein and had either a low or high calcium concentration. The low (on average $0.55 \mathrm{~g}$ of $\mathrm{Ca} / 100 \mathrm{~g}$ of air-DM) and high calcium level (on average $1.16 \mathrm{~g}$ of $\mathrm{Ca} / 100 \mathrm{~g}$ of air-DM) were chosen on the basis of earlier research showing an inhibitory effect of the high calcium level on fat digestibility (Xu et al., 1998). The variable protein source was added at a level of about $50 \%$ of the total amount of protein in the diet. The inclusion level of casein and soy protein isolate was expected to elicit a protein effect on fat digestibility (Xu et al., 1997). Calcium was added to the high-calcium diets in the form of calcium formiate and carbonate. Tables 1 and 2 show the ingredient and calculated nutrient composition of the diets. The milk replacers were reconstituted in hot water $\left(65^{\circ} \mathrm{C}\right)$ and fed at a temperature of about $42^{\circ} \mathrm{C}$. Upon arrival, the calves received $1.7 \mathrm{~L}$ containing $125 \mathrm{~g}$ of air-dry milk replacer per meal, the volume being increased to $6.5 \mathrm{~L}$ per meal after 7 wk; each week the volume was raised by $0.8 \mathrm{~L}$. The starter milk replacer was then replaced by the finisher diets (125 g of air-dry milk replacer/L) in equal steps over a period of $4 \mathrm{~d}$. After the replacement was complete, the concentration of the finisher milk replacer was increased to $145 \mathrm{~g}$ of air-dry milk replacer/L within 10 wk and the volume from 5.8 to $8.2 \mathrm{~L}$ within $6 \mathrm{wk}$. The increases in milk replacer concentration and volume took place each week and were equal for each week. The volume was then kept constant until wk 23, i.e., the end of the trial.

\section{Collection of Samples}

Feces were collected quantitatively for a period of 5 $\mathrm{d}$ during wk 7, 17, and 23 of the experiment. Feces collection was performed by the use of plastic trays that
Table 1. Composition of the experimental starter diets.

\begin{tabular}{|c|c|c|c|c|}
\hline Ingredients & $\begin{array}{l}\text { Casein } \\
\mathrm{LCa}^{1}\end{array}$ & $\begin{array}{l}\text { SPI } \\
\text { LCa }\end{array}$ & $\begin{array}{l}\text { Casein } \\
\mathrm{HCa}\end{array}$ & $\begin{array}{l}\text { SPI } \\
\mathrm{HCa}\end{array}$ \\
\hline & \multicolumn{4}{|c|}{$\mathrm{g} / 100 \mathrm{~g}$ of air-DM } \\
\hline Casein & 11.25 & & 11.25 & \\
\hline Soy isolate $^{2}$ & & 11.25 & & 11.25 \\
\hline Whey protein & 12.5 & 12.5 & 12.5 & 12.5 \\
\hline Lard & 5 & 5 & 5 & 5 \\
\hline Tallow & 11.65 & 11.4 & 11.65 & 11.35 \\
\hline Coconut oil & 3 & 3 & 3 & 3 \\
\hline Lecithin & 0.65 & 0.65 & 0.65 & 0.65 \\
\hline Whey powder & 34.35 & 31.9 & 33.2105 & 31.155 \\
\hline Delactosed whey powder & 10.9105 & 14.25 & 11.45 & 14.545 \\
\hline Wheat starch & 7.15 & 7.15 & 7.15 & 7.15 \\
\hline Lysine & 0.425 & $\ldots$ & 0.425 & $\ldots$ \\
\hline Methionine & 0.21 & $\ldots$ & 0.21 & $\ldots$ \\
\hline Fumaric acid & 1.25 & 1.25 & $\ldots$ & $\ldots$ \\
\hline $\mathrm{FeSO}_{4}, 31 \%$ & 0.0045 & $\ldots$ & 0.0045 & \\
\hline Calcium formiate & $\ldots$ & $\ldots$ & 1.25 & 1.25 \\
\hline $\mathrm{CaCO}_{3}$ & $\ldots$ & & 0.6 & 0.5 \\
\hline Premix starter ${ }^{3}$ & 1.65 & 1.65 & 1.65 & 1.65 \\
\hline \multicolumn{5}{|l|}{ Analyzed contents } \\
\hline $\mathrm{CP}$ & 21.66 & 21.31 & 21.29 & 21.18 \\
\hline Crude fat & 21.89 & 22.43 & 23.32 & 22.10 \\
\hline Carbohydrates $^{4}$ & 45.4 & 44.5 & 43.6 & 42.9 \\
\hline Crude ash & 6.21 & 6.63 & 7.03 & 7.45 \\
\hline Calcium & 0.58 & 0.69 & 1.16 & 1.14 \\
\hline Phosphorus & 0.61 & 0.64 & 0.63 & 0.63 \\
\hline Magnesium & 0.22 & 0.20 & 0.20 & 0.22 \\
\hline
\end{tabular}

${ }^{\mathrm{a}}$ Casein $\mathrm{LCa}=$ casein with low concentration of calcium; Casein $\mathrm{HCa}=$ casein with high concentration of calcium; SPI LCa $=$ soy protein isolate with low concentration of calcium; SPI $\mathrm{HCa}=$ soy protein isolate with high concentration of calcium.

${ }^{2}$ Nurish 1591, Protein Technologies International, St. Louis, MO.

${ }^{3}$ Van Drie Group, Mijdrecht, The Netherlands.

${ }^{4}$ Calculated as residual fraction.

were placed under the slatted floors of the pens. On each collection day, feces were removed from the trays, weighed, and homogenized with tap water (1:0.5, wt/ wt). Each day's homogenate samples were taken as 5 percentage of total daily fecal production and then pooled per calf and stored at $-20^{\circ} \mathrm{C}$ until the time of analysis. Reconstituted milk was collected during the feces collection period and the samples were pooled per diet and stored at $-20^{\circ} \mathrm{C}$ until the time of analysis.

\section{Chemical Analyses}

Reconstituted milk and feces samples were freezedried. Total nitrogen content of all samples was determined by the Kjeldahl method (IDF, 1986). Crude protein was calculated as gram of nitrogen $\times 6.25$. After acidification of the samples with $8 \mathrm{M} \mathrm{HCl}$, total lipids in the samples were extracted with diethyl ether and petroleum ether (boiling point 40 to $60^{\circ} \mathrm{C}$ ) and measured gravimetrically (AOAC, 1975). Total bile acids in feces samples were extracted using 50\% t-butanol and then measured on a COBAS-BIO centrifugal analyzer 
Table 2. Composition of the experimental finisher diets.

\begin{tabular}{|c|c|c|c|c|}
\hline Ingredients & $\begin{array}{l}\text { Casein } \\
\mathrm{LCa}^{1}\end{array}$ & $\begin{array}{l}\text { SPI } \\
\text { LCa }\end{array}$ & $\begin{array}{l}\text { Casein } \\
\mathrm{HCa}\end{array}$ & $\begin{array}{l}\text { SPI } \\
\text { HCa }\end{array}$ \\
\hline & & \multicolumn{2}{|c|}{$\mathrm{g} / 100 \mathrm{~g}$ of air-DM } & \\
\hline Casein & 10.625 & & 10.625 & \\
\hline Soy isolate ${ }^{2}$ & $\ldots$ & 10.625 & & 10.625 \\
\hline Lard & 5 & 5 & 5 & 5 \\
\hline Tallow & 10.9 & 10.7 & 10.95 & 10.7 \\
\hline Coconut oil & 4 & 4 & 4 & 4 \\
\hline Lecithin & 0.65 & 0.65 & 0.65 & 0.65 \\
\hline Whey powder & 56.071 & 53.975 & 54.781 & 52.925 \\
\hline Delactosed whey powder & 2.1 & 5 & 2.65 & 5.45 \\
\hline Wheat starch & 7.15 & 7.15 & 7.15 & 7.15 \\
\hline Lysine & 0.40 & $\ldots$ & 0.40 & $\ldots$ \\
\hline Methionine & 0.20 & $\ldots$ & 0.20 & $\ldots$ \\
\hline Fumaric acid & 1.25 & 1.25 & & $\ldots$ \\
\hline $\mathrm{FeSO}_{4}$ & 0.004 & $\ldots$ & 0.004 & $\ldots$ \\
\hline Calcium formiate & $\ldots$ & $\ldots$ & 1.25 & 1.25 \\
\hline $\mathrm{CaCO}_{3}$ & $\ldots$ & $\ldots$ & 0.69 & 0.6 \\
\hline Premix finisher ${ }^{3}$ & 1.65 & 1.65 & 1.65 & 1.65 \\
\hline \multicolumn{5}{|l|}{ Analyzed contents } \\
\hline $\mathrm{CP}$ & 18.02 & 18.27 & 18.92 & 18.28 \\
\hline Crude fat & 21.72 & 21.85 & 21.66 & 21.80 \\
\hline Carbohydrates ${ }^{4}$ & 50.8 & 50.0 & 48.9 & 48.2 \\
\hline Crude ash & 5.30 & 5.74 & 6.67 & 7.24 \\
\hline Calcium & 0.44 & 0.48 & 1.17 & 1.15 \\
\hline Phosphorus & 0.47 & 0.49 & 0.52 & 0.54 \\
\hline Magnesium & 0.17 & 0.19 & 0.19 & 0.20 \\
\hline
\end{tabular}

${ }^{\mathrm{a}}$ Casein $\mathrm{LCa}=$ casein with low concentration of calcium; Casein $\mathrm{HCa}=$ casein with high concentration of calcium; SPI LCa = soy protein isolate with low concentration of calcium; SPI $\mathrm{HCa}=$ soy protein isolate with high concentration of calcium.

${ }^{2}$ Soyco milk, Loders Croklaan B.V., Wormerveer, The Netherlands.

${ }^{3}$ Van Drie Group, Mijdrecht, The Netherlands.

${ }^{4}$ Calculated as residual fraction.

(Roche Diagnostics, Basel, Switzerland) with a commercial test combination (Sigma 450-A, Sigma Diagnotics). Both reconstituted milk and feces were dried at $105^{\circ} \mathrm{C}$ for $16 \mathrm{~h}$ for moisture determination. Then, the samples were ashed at $500^{\circ} \mathrm{C}$ for $17 \mathrm{~h}$ and the ash was weighed. For analysis of minerals in the reconstituted milk and feces, the ash was dissolved in $6 \mathrm{M} \mathrm{HCl}$. Calcium and magnesium were estimated by flame atomic absorption spectroscopy (Varian-250 plus; Varian Australia Pty Ltd., Mulgrave, Victoria, Australia). Total phosphorus was determined by spectrophotometry according to the method of Quinlan and Desesa (1955).

\section{Calculations and Statistical Analysis}

The apparent nutrient digestibility was expressed as percentage of intake and computed as (intake - output with feces) $\times$ intake $^{-1} \times 100 \%$.

There was no statistically significant period effect on the apparent digestibilities of DM, total fat, calcium, phosphorus, and magnesium and on fecal bile excretion. The digestibility data were then pooled for the 3 feces collection periods and were statistically analyzed by subjecting them to repeated measures ANOVA. In the ANOVA, the protein (casein vs. soy protein isolate) and calcium (low vs. high calcium) main effects were evaluated, as well as their interaction. Differences between treatment means were evaluated with the use of the Tukey test. The data on fecal bile excretion were not normally distributed (Kolmogorov-Smirnov test) and the rank order correlation coefficient for the relationship between bile acid excretion and fat digestibility was calculated with the Spearman method. For all statistical analyses the computer program SPSS for Windows 9.0 was used (SPSS Inc., Chicago, IL). Throughout, the level of statistical significance was preset at $P$ $<0.05$.

\section{RESULTS}

\section{Growth Performance}

Growth performance of the veal calves did not differ significantly among the experimental diets (Table 3 ). Due to feed refusals, feed intake differed somewhat between the groups. The calves fed the milk replacers containing soy protein isolate had numerically lower, but not significantly different, group-mean weight gain when compared with the calves fed the milk replacers containing casein, irrespective of calcium intake. Body weight gain of the calves fed soy protein isolate with different amounts of calcium was similar. It is interesting to note that calves fed the high-calcium casein diet had the numerically highest weight gain, but the difference with the other groups was not statistically significant.

\section{Digestibility of DM and Total Fat}

The apparent digestibilities of DM and total lipids are shown in Table 4. The apparent digestibilities of DM and total lipids were lower in calves fed soy protein isolate than in calves fed casein, irrespective of calcium intake. The calves fed the low-calcium diets had greater digestibilities of DM and total lipids than did the calves fed the high-calcium diets. The inhibitory effect of soy protein versus casein on apparent fat digestibility was 3.6 percentage units for the high-calcium diets and 2.9 percentage units for the low-calcium diets, but the interaction did not reach statistical significance.

\section{Absorption of Minerals}

Calves fed the high-calcium diets had lower apparent absorptions of calcium, phosphorus, and magnesium than did the calves fed the low-calcium diets, irrespective of the source of protein (Table 4). Soy protein fed calves had a lower apparent mineral absorption than 
Table 3. Growth performance of veal calves fed milk replacers containing either casein or soy protein isolate with either low or high calcium concentration. ${ }^{1}$

\begin{tabular}{llllll}
\hline & $\begin{array}{l}\text { Casein } \\
\mathrm{LCa}^{2}\end{array}$ & $\begin{array}{l}\text { SPI } \\
\text { LCa }\end{array}$ & $\begin{array}{l}\text { Casein } \\
\text { HCa }\end{array}$ & $\begin{array}{l}\text { SPI } \\
\text { HCa }\end{array}$ & $\begin{array}{l}\text { Pooled } \\
\text { SD }\end{array}$ \\
\cline { 2 - 3 } & & & & & \\
Body weight & & & & & \\
Initial & 47.4 & 47.0 & 47.0 & 46.0 & 4.64 \\
Week 6 & 83.4 & 82.3 & 83.4 & 83.9 & 7.65 \\
Final & 207.5 & 204.7 & 213.3 & 203.1 & 20.47 \\
BW gain & 160.3 & 157.7 & 166.3 & 157.2 & 18.60 \\
Average daily gain & 0.998 & 0.980 & 1.034 & 0.971 & 0.096 \\
Feed intake & 374.0 & 366.8 & 374.3 & 359.1 & \\
\hline
\end{tabular}

${ }^{1}$ Results are for wk 0 to 23 wk of the experiment and given for 19 calves in the Casein LCa and casein $\mathrm{HCa}$ groups and for 18 calves in the soy $\mathrm{LCa}$ and soy HCa groups. There were no significant differences between the treatment groups.

${ }^{2}$ Casein $\mathrm{LCa}=$ casein with low concentration of calcium; Casein $\mathrm{HCa}=$ casein with high concentration of calcium; SPI LCa = soy protein isolate with low concentration of calcium; SPI $\mathrm{HCa}=$ soy protein isolate with high concentration of calcium.

${ }^{3}$ Standard deviations are not given for feed intake because the calves were fed restricted amounts of milk replacers.

calves fed casein, irrespective of calcium intake. There was no interaction between the dietary level of calcium and the type of protein.

\section{Fecal Bile Acids Excretion}

Calves fed the diets high in calcium excreted more bile acids in feces than did calves fed the low-calcium diets, irrespective of the source of protein (Table 4). Soy protein-fed calves had greater fecal bile acid excretion than casein-fed calves, irrespective of the level of calcium intake. There was a significant interaction of the source of protein and level of calcium intake as to bile acid excretion in feces.

\section{DISCUSSION}

It is well known that veal calves fed soy protein preparations show impaired weight gain compared with calves fed dairy proteins (Nitsan et al., 1971; Beynen and Van Gils, 1983; Lallès et al., 1995; Xu et al., 1997). The lower weight gain in calves fed soy protein is explained, at least in part, by a diminished fat digestion (Xu et al., 1997). As far as we know, this is the first study with veal calves that compares the relatively pure protein preparations, casein and soy protein isolate. Indeed, casein versus soy protein isolate depressed fat digestibility. Weight gain on average was higher in the calves fed casein, but the increase did not reach statisti-

Table 4. Apparent digestibility of dry matter, total fat, calcium, phosphorus, magnesium and fecal bile acids excretion in veal calves fed milk replacers containing either casein or soy protein isolate with either low or high calcium concentration ${ }^{1}$

\begin{tabular}{|c|c|c|c|c|c|c|c|c|}
\hline & $\begin{array}{l}\text { Calcium } \\
\mathrm{LCa}^{2}\end{array}$ & $\begin{array}{l}\text { SPI } \\
\text { LCa }\end{array}$ & $\begin{array}{l}\text { Casein } \\
\mathrm{HCa}\end{array}$ & $\begin{array}{l}\text { SPI } \\
\mathrm{HCa}\end{array}$ & $\begin{array}{l}\text { Pooled } \\
\text { SD }\end{array}$ & $\mathrm{Ca}^{3}$ & $\operatorname{Pr}$ & $\mathrm{CaxPr}$ \\
\hline & \multicolumn{8}{|c|}{$\Psi$ of intake -} \\
\hline $\mathrm{DM}$ & $96.6^{\mathrm{a}}$ & $95.3^{\mathrm{b}}$ & $95.2^{\mathrm{b}}$ & $93.5^{\mathrm{c}}$ & 1.11 & $<0.001$ & $<0.001$ & 0.856 \\
\hline Total fat & $96.1^{\mathrm{a}}$ & $92.5^{\mathrm{b}}$ & $93.2^{\mathrm{b}}$ & $90.3^{\mathrm{c}}$ & 1.46 & $<0.001$ & $<0.001$ & 0.610 \\
\hline Calciu & $92.4^{\mathrm{a}}$ & $87.4^{\mathrm{b}}$ & $77.4^{\mathrm{c}}$ & $72.4^{\mathrm{d}}$ & 8.82 & $<0.001$ & $<0.001$ & 0.686 \\
\hline Phosphorus & $95.2^{\mathrm{a}}$ & $92.3^{\mathrm{a}}$ & $86.7^{\mathrm{b}}$ & $82.7^{\mathrm{c}}$ & 6.08 & $<0.001$ & $<0.001$ & 0.636 \\
\hline Magnesium & $67.5^{\mathrm{a}}$ & $61.1^{\mathrm{b}}$ & $60.8^{\mathrm{b}}$ & $55.6^{\mathrm{b}}$ & 7.23 & $<0.001$ & 0.001 & 0.313 \\
\hline Fecal bile excretion, $\mu \mathrm{mol} / \mathrm{d}$ & $138^{\mathrm{b}}$ & $212^{\mathrm{b}}$ & $186^{\mathrm{b}}$ & $406^{\mathrm{a}}$ & 146 & $<0.001$ & $<0.001$ & $<0.001$ \\
\hline
\end{tabular}

${ }^{a, b, c, d}$ Values in the same row with different superscript differ significantly $(P<0.05)$.

${ }^{1}$ Results are given for 19 calves in the Casein LCa and Casein HCa groups and for 18 calves in the Soy $\mathrm{LCa}$ and Soy HCa groups. The data presented are means based on the average values of each calf for the three feces collection periods.

${ }^{2}$ Casein $\mathrm{LCa}=$ casein with low concentration of calcium; Casein $\mathrm{HCa}=$ casein with high concentration of calcium; SPI $\mathrm{LCa}=$ soy protein isolate with low concentration of calcium; SPI $\mathrm{HCa}=$ soy protein isolate with high concentration of calcium.

${ }^{3}$ Significance: $\mathrm{P}$ value for $\mathrm{Pr}=$ protein effect; $\mathrm{Ca}=$ calcium effect; $\mathrm{Pr} \times \mathrm{Ca}=$ protein-calcium interaction. 
cal significance. The order of magnitude of the increased final BW in the calves fed casein was similar to that seen earlier in calves fed skim milk powder when compared with calves fed soy protein preparations (Nitsan et al., 1971; Beynen and Van Gils, 1983; Lallès et al., 1995; Xu et al., 1997).

The feeding of soy protein, which is a poorly phosphorylated protein, produces extra calcium phosphate sediment in the small intestinal digesta. This sediment will bind bile acids, which impairs bile acids to participate in the process of fat digestion. Hence, fat digestion is depressed and the excretion of bile acids in feces elevated (Xu et al., 1997). As would be anticipated, fecal bile acid excretion was greater in calves fed soy protein than in calves fed casein. In veal calves, the feeding of extra calcium has been shown to raise fecal bile acid excretion (Xu et al., 1998), and this effect is explained by the formation of extra calcium phosphate sediment in the small intestinal lumen (Beynen et al., 2002). This experiment confirms the calcium-induced increase in fecal bile acid excretion, but also shows an interaction between the source of protein and level of calcium intake as to fecal bile acid excretion. Against a high calcium background, the increase in bile acid excretion as induced by soy protein versus casein was more pronounced. In contrast, the soy protein-induced decrease in fat digestion was smaller when the diets were rich in calcium. This observation could indicate that bile acid excretion and fat digestion are not negatively related, as was shown earlier (Xu et al., 2001). However, for individual calves there indeed was a negative correlation (Figure 1).

When the calves were fed the milk replacer high in calcium and containing casein, the BW gain was numerically highest, albeit that the difference when compared with the other groups was not statistically significant. This observation is surprising, because the addition of extra calcium to the diet lowered the digestibility of both DM and fat without affecting feed intake. The high calcium intake possibly had protected the calves against pathogens. In rats, diets high in calcium can reduce the colonization of pathogens such as salmonella (Bovee-Oudenhoven et al., 1999). It should be noted that the stimulatory effect of calcium on growth was not observed when soy protein isolate was a component of the milk replacer.

As would be expected on the basis of earlier studies with veal calves fed either dairy proteins or soy protein (Xu et al., 1997), the absorption of phosphorus, calcium, and magnesium in calves fed soy protein was lower than in calves fed casein. In keeping with a previous study (Xu et al., 1998), mineral absorption was lower in calves fed high instead of low calcium diets. As explained above, soy protein versus casein or high versus

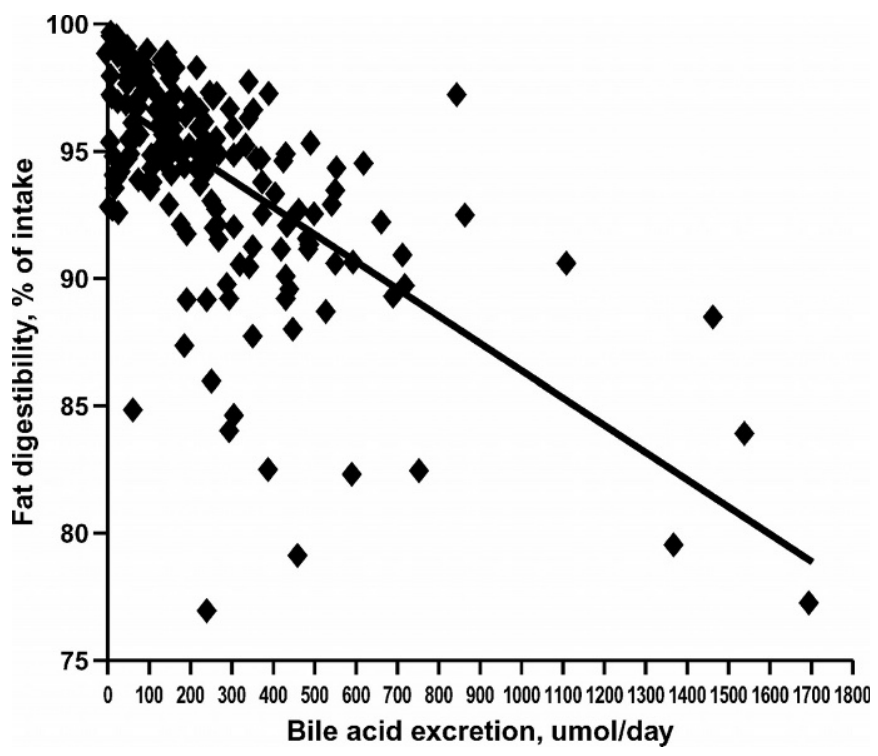

Figure 1. Relationship between fecal bile acid excretion and apparent fat digestibility in individual veal calves fed milk replacers containing either casein or soy protein isolate with either low or high calcium concentration. The data for the three feces collection periods have been pooled and dependence of the values was not taken into account. The rank order correlation coefficient is $\mathrm{R}=0.71$. $(P=0.001$, $\mathrm{n}=222$ ).

low calcium intake may induce extra formation of insoluble calcium phosphate sediment in the small intestinal digesta. Thus, these minerals become less soluble and thus unavailable for absorption. The lower magnesium absorption can be explained as this mineral also is a component of the sediment (Brink et al., 1992).

Our hypothesis was that high calcium intake would reduce the inhibitory effect of soy protein versus casein on fat digestion. The hypothesis cannot be rejected by the experimental data, but there is no solid proof for it either. This study does indicate clearly that the enhanced growth and fat digestion, seen generally in calves fed skim milk powder instead of soy protein, is caused, at least in part, by the casein component of dairy proteins. The present results may extend to the practice of milk replacer formulation. To enhance fat digestibility by veal calves, high inclusion levels of calcium and/or soybean protein preparations should be avoided.

\section{ACKNOWLEDGMENTS}

This study was supported by The Netherlands Foundation for Nutrition and Health Research, Loders Croklaan B. V., Wormerveer, and the Van Drie Group, Mijdrecht, The Netherlands. The authors thank Robert Hovenier, Hugo Wouterse, Jan van der Kuilen and Inez Lemmens for analytical assistance, Bart Eves and Fa- 
bian Hack for assistance with feces collection and Bert van Beek for taking care of the calves.

\section{REFERENCES}

Association of Official Analytical Chemists. 1975. Official Methods of Analysis. 12th ed. W. Horwitz, ed., AOAC, Washington, DC.

Best, P. 1995. User-friendly milk replacers. Feed International, Feb., pp 6-8.

Beynen, A. C., M. J. De Graaf, and A. G. Lemmens. 2002. Cholate feeding counteracts calcium-induced depression of apparent fat digestibility in rats. Int. J. Vitam. Nutr. Res. 72:372-374.

Beynen, A. C., and L. G. M. Van Gils. 1983. Postprandial changes in the levels of lipids, glucose, urea and nonprotein nitrogen in the serum of veal calves fed milk replacers containing either skim-milk powder or soybean protein concentrate. Z. Tierphysiol. Tierernährg. Futtermittelkde. 49:49-56.

Bovee-Oudenhoven, I. M., M. L. Wissink, J. T. Wouters, and R. Van der Meer. 1999. Dietary calcium phosphate stimulates intestinal lactobacilli and decreases the severity of a salmonella infection in rats. J. Nutr. 129:607-612.

Brink, E. J., A. C. Beynen, P. R. Dekker, E. C. H. Van Beresteijn, and R. Van der Meer. 1992. Interaction of calcium and phosphate decreases ileal magnesium solubility and apparent magnesium absorption in rats. J. Nutr. 122:580-586.

Govers, M. J. A. P., D. S. M. L. Termont, G. A. Van Aken, and R. Van der Meer. 1994. Characterization of the adsorption of conjugated and unconjugated bile acids to insoluble, amorphous calcium phosphate. J. Lipid Res. 35:741-748.
International Dairy Federation, 1986. IDF Standard 20 A. Int. Dairy Fed., Brussels, Belgium.

Lallès, J. P., R. Toullec, P. B. Pardal, and J. W. Sissons. 1995. Hydrolyzed soya protein isolate sustains high nutritional performance in veal calves. J. Dairy Sci. 78:194-204.

Nitsan, Z., R. Volcani, S. Gordin, and A. Hasdai. 1971. Growth and nutrient utilisation by calves fed milk replacers containing milk or soybean protein concentrate heated to various degrees. J. Dairy Sci. 54:1294-1299.

Quinlan, K. P., and M. A. Desesa. 1955. Spectrophotometric determination of phosphorus as molybvanadophosphoric acid. Anal. Chem. 27:1626-1629.

Van Kempen, G. J. M., and J. Huisman. 1991. Introductory remarks: Some aspects of skim-milk replacement by other protein sources in veal-calf diets. Pages 201-205 in New Trends in Veal Calf Production. J. H. M. Metz and C. M. Groenestein, eds. Pudoc, Wageningen, The Netherlands.

Van der Meer, R., H. T. De Vries, C. E. West, and H. De Waard. 1985. Casein-induced hypercholesterolaemia in rabbits is calcium-dependent. Atheroslerosis 56:139-147.

Xu, C., T. Wensing, R. Van der Meer, and A. C. Beynen. 1997. Mechanism explaining why dietary soya protein versus skim-milk protein lowers fat digestion in veal calves. Livest. Prod. Sci. 52: 219-227.

Xu, C., T. Wensing, and A. C. Beynen. 1998. The effect of high calcium intake on fat digestion and fecal bile acid excretion in veal calves. J. Dairy Sci. 81:2173-2177.

Xu, C., T. Wensing, and A. C. Beynen. 2001. Apparent fat digestibility in rats fed different diets is negatively correlated with faecal bile acid excretion. Int. J. Vitam. Nutr. Res. 71:251-253. 